\title{
THE TOLERANT SOCIETY AND ITS ENEMIES: MORAL RELATIVISM, MULTICULTURALISM, AND ISLAMISM
}

\author{
T. M. MURRAY*
}

Fine Arts College, London

\begin{abstract}
In this paper, T. M. Murray defends a vision of liberal tolerance as grounding the common good. She critiques the discourse that Western liberalism amounts to 'Islamophobia' or 'cultural imperialism'. She argues that liberal academics, in maintaining these narratives, contradict their own vaunted values and tacitly collude with religious hypocrisy and intolerance. She argues for a universal vision of the common good broadly grounded in human flourishing and human nature and linked to the philosophies of Aristotle and J. S. Mill.
\end{abstract}

KEYWORDS: multiculturalism, liberalism, tolerance, universalism, relativism

Let me begin by stating that by 'multiculturalism' I do not simply mean cultural diversity. By 'multiculturalism' I mean an approach to dealing with the relationship between specific cultures and other members of a liberal society. Multiculturalism developed out of the belief that liberalism's goals of universal citizenship, equal legal status and entitlements, and equality of opportunity were insufficient and that, in addition, citizens in liberal democracies ought to be obliged to 'recognize' and demonstrate positive respect for members of a cultural minority, should not be permitted to offend them, and must participate in the protection of their sacred beliefs from insult or criticism. (Heywood 2009: 25). In addition, defenders of multiculturalism have demanded legal privileges or exclusions that enable particular religiously or culturally defined groups to maintain their distinctive identities or practices, sometimes at the expense of the rights of other individuals (within and/or outside of those cultures) or groups.

One result of multiculturalist policies is that the annihilation of the 'other' is regarded as an exclusively Western phenomenon. When it comes to ethnic groups themselves, the rights of dissenting minorities within these groups are

* T. M. MURRAY (PhD 2015 Philosophy, Oxford Brookes University) is Director of Studies at Fine Arts College, London, United Kingdom. Email: Terri.Murray@hampsteadfinearts.com. 
rarely defended. The multicultural agenda treats ethnic subcultures as homogeneous 'communities', as though individuals within them unanimously share a common identity defined solely, or primarily, by their common heritage or religion. Consequently, multiculturalist policies treat discrimination against 'others' as acceptable, so long as the group responsible for doing so is ethnic. This can leave minority ethnic individuals unprotected from a tyranny of the majority within their own communities.

Multiculturalism trades on the political fiction of community cohesion, a false consensus that can easily be transformed into a reality by means of various forms of coercion. Too often internal customs, taboos, social pressures and stigma are not just tolerated but supported and/or promoted by the host culture or its government.

In order to understand how illiberal multiculturalism is, and what kinds of demands it places on citizens, it is also important to understand its paternalistic approach to enforcing 'respect' for religions or religious belief. It does not require that respect be earned through robust debate and argument. Rather, 'respect' is the demand not to subject religion to critical scrutiny and is enforced under threat of legal sanction or penalty.

On the international stage, this form of enforced respect has gained steady ground in the past two decades. The Organisation of Islamic Cooperation (OIC) is the self-proclaimed representative body of the Universal Ummah: which it describes as a community of more than 1.5 billion Muslims It is the second largest intergovernmental organisation after the United Nations (Cliteur and Herrenberg 2016: 179).

The OIC's 1999 introduction of their draft resolution on 'Defamation of Islam" contained an all-important conflation of religion and race. The resolution adopted liberal language redolent of Western critiques of racism (hatred, intolerance, discrimination) but applied it to the protection of Islam (an ideology and set of values). Instead of dismissing the OIC's whole line of reasoning as misleading, the EU member states took an accommodating stance and decided instead to correct the exclusivity of religious protection by broadening it to all religions. This move gave the OIC room to introduce the religious defamation concept. Consequently, in 2001 Pakistan, acting on behalf of the OIC, introduced a resolution titled: 'Combating defamation of religion as a means to promote human rights, social harmony and religious and cultural diversity.'

Despite the fact that this resolution served to protect religions rather than the human rights of persons, it was adopted by 28 votes in favour with 15 against, and 9 abstentions. This laid the ground for what would follow in subsequent years.

A similar attenuation of religious liberty under the guise of 'respect' has occurred at the national level in the UK. In modern multicultural Britain, for 
example, Rumy Hasan, a senior lecturer at University of Sussex, has provided insightful analysis of the tensions between blasphemy law and freedom of expression (Cliteur and Herrenberg 2016: 209-233). Hasan has observed how public figures accepted and even helped to promote a gradual conflation of race/ethnicity with culture/religion in the wake of the Rushdie Affair.

In its 2005 general election manifesto, the UK Labour Party promised to introduce a Bill designed to outlaw 'incitement to religious hatred". Without any serious debate, the role of religion was given decisive importance in the national identity. Euphemistic language such as 'protection' and 'tolerance' was used and the promised Bill was duly passed by Parliament in the form of The Racial and Religious Hatred Act 2006, which went into force on 1 October 2007.

Hasan points out that, as with international legislation, the language of this Act is sufficiently vague to effectively outlaw virtually anything a religious believer finds offensive. The wording of sections 29B(1) and 29J are in conflict. The former stipulates that a person is guilty of the crime if he 'displays any written material which is threatening' and 'intends thereby to stir up religious hatred'. The latter states, 'Nothing in this section shall be read or given effect in a way which prohibits or restricts ... expressions of antipathy, dislike, insult or abuse of particular religions or the beliefs or practices of their adherents.' Either could potentially cancel the other out-the question remains which one will be given precedence.

In identifying an incident of speech or expression as a 'hate crime' the victim's perception is given grossly disproportionate weight, such that no material evidence is needed in order to record and flag an incident as a 'hate crime'. In order to identify racist or religious hate incidents/crimes and to monitor its decisions and outcomes the Crown Prosecution Service uses this definition:

'Any incident/crime which is perceived by the victim or any other person to be motivated by hostility or prejudice based on a person's race or perceived race'

or

'Any incident/crime which is perceived by the victim or any other person to be motivated by a hostility or prejudice based on a person's religion or perceived religion.' [my emphasis]

Interestingly, hostility is not defined in the legislation. The CPS instead states that, 'Consideration should be given to ordinary dictionary definitions, which include ill-will, ill-feeling, spite, prejudice, unfriendliness, antagonism, resentment, and dislike.' [my emphases] The Crown Prosecution Service also specifies that, 'it is not CPS policy to remove a flag in the absence of sufficient 
evidence to support a sentence uplift.' The wording here is full of double negatives and is almost indiscipherable. It appears to mean that the CPS will not remove a flag in instances where there is insufficient evidence to lift the sentence, i.e., where the charges are upheld. Their intent is the opposite, however. This can only be discerned from the wider context where they justify their highly unorthodox approach to statistical recording as follows: 'This in part reflects the commitment to treat hate crime seriously and to support the victim's perception and also to encourage community confidence in reporting all such offending.' [my bold] The interpretation that accurately reflects the intent and the reality of what is going on is that the CPS will not remove a flag (i.e. a record of the incident as a 'hate crime') even where there is insufficient evidence to support a conviction/sentence. The law is itself an instance of gross prejudice in favor of the perceived 'victim' and in practice functions to inflate statistics of actual hate crimes by conflating substantiated claims with insubstantial ones - treating them as equally grave. The result is a chilling effect and the criminalization of even mild disagreement with a religious person or his/her beliefs, even when it is a mistaken instance of 'hate crime'. And while the legislation nominally protects apostates and non-religious believers, it simultaneously functions as a de facto blasphemy law. There is so much scope for prosecution and so much elasticity to this law that it places virtually no limits on what constitutes a hate crime while also allowing for highly selective prosecution. Further 'community confidence in reporting' came in the form of actively using taxpayer funding to solicit hate crime reporting, through the use (or abuse) of widely distributed local council magazines, in which readers were reminded of the definition and scope of 'hate crimes' and given detailed information on how to report them to a dedicated 24 hour hotline (Camden Council 2018).

In his book Why Tolerate Religion?, Brian Leiter distinguishes between 'recognition respect' and 'appraisal respect'. The latter involves the notion that religious convictions per se have a special kind of value that others (including the non-religious) should appraise highly.

British philosopher Simon Blackburn has also noted that 'respect' is an ambiguous term. He describes the phenomenon by which the request for principled toleration 'turns into a demand for more substantial respect, such as fellow-feeling, or esteem, and finally deference and reverence' (Blackburn 2007: 180). This 'respect creep' (Blackburn's term) goes beyond liberty to practice religion without interference. It imposes a claim right on others that requires far more than merely tolerating religious beliefs while perhaps at the same time finding them unpersuasive or even immoral. It is a positive demand that everyone in society must behave as though they are silent or vocal followers of the 'other's' belief system. This effectively turns the concept of tolerance into deference or adherence. In his 2017 Voltaire Lecture, 
British political columnist Nick Cohen also pointed out that 'respect' is an ambiguous term and that a climate of coerced respect only fosters a definition akin to the kind of 'respect' that gangsters like Tony Soprano might demand.

Multiculturalism has been shaped by a politics of self-assertion that has links with identity politics and communitarianism. From identity politics it takes the view that liberal universalism and inclusivity are forms of 'cultural imperialism'. From communitarianism it adopts the belief that individuals are constituted by the social institutions of the communities to which they belong and that, as such, they owe these institutions a debt of obedience and respect (Heywood 2009: 26).

As an ideology, multiculturalism encompasses a variety of approaches. Liberal multiculturalism accepts diversity within a liberal framework and rejects illiberal or intolerant cultural practices. The kind of multiculturalism that I think poses a threat to the tolerant society is pluralist multiculturalism. Pluralist multiculturalists place a greater emphasis on diversity than on equal rights and equal opportunities for all. They campaign for value pluralism and moral relativism: the idea that different moral beliefs (both those that respect autonomy and individual liberty and theocratic, fundamentalist or authoritarian ideologies that do not) are equally legitimate. Consequently, what they refer to as 'diversity' has often been a euphemism for culture or religious belief that diverges from the western liberal political model. On this model, diversity is not really about intellectual diversity or a variety of worldviews or opinions being allowed into the public square. This is what liberals mean by diversity. Rather, what pluralist multiculturalists mean by 'diversity' is a claim right to deference that places a demand on Westerners to adopt a posture of positive regard towards non-Western belief systems in general and Islam in particular. In the United Kingdom this has been codified into law.

\section{Liberal Multiculturalism: a More Genuine Diversity}

In what follows, I will offer a few reasons why I think liberalism, as a political philosophy, is not only still relevant, but highly commendable, and then I will briefly state why I think liberal multiculturalism is preferable to pluralist multiculturalism as a framework within which disputes about the common good can be resolved.

The liberal state is designed to protect its citizens from both external threats and from itself, as well as from internal threats that can arise from a tyranny of the majority in society. The pursuit of values that constitutes the 'good life' (however one defines it) is not possible where said 'values' are coerced. Values, by definition, require conviction by means of persuasion, not coercion by means of intimidation. Those who reject self-determination for others invariably want it for themselves. Arguably, the freedom to pursue goals that are genuinely one's own is a necessary condition for human 
flourishing. Few who would deprive others of this basic condition would allow it to be removed from themselves or from their own community or identity group.

In the third chapter of On Liberty, John Stuart Mill (1806-1873) identified individuality as "quite the chief ingredient of individual and social progress' and argued that the free development of individuality is 'one of the leading essentials of well-being' (Collini 1989: 57). Mill claimed that where a person's 'rule of conduct' came not from within but from slavish obedience to 'the traditions or customs of other people' a principal ingredient of happiness would be lacking (Collini 1989: 58-9). This insight also forms the basis of the anti-colonial liberation movements of the mid-twentieth century. Mill was not opposed to conformity when it is an informed choice. But he did oppose blindly following custom, for example, when the 'grounds of an opinion are not conclusive to the person's own reason' or where the 'inducements to an act are not such as are consentaneous to his own feelings and character. In these circumstances, conformity only weakens the faculties of perception, judgment, discriminative feeling, mental activity, and even moral preference. Ultimately, such 'ape-like imitation' leads to the atrophy of the highest and best intellectual potentials in individuals and prevents the full development of the human person (Collini 1989: 59).

Mill's understanding of human well-being draws strikingly on virtue ethics (Stonestreet 2009: 17). In Chapter 4 of the Nicomachean Ethics Aristotle identifies happiness (eudaimonia) as the good for which all humans strive. By 'eudaimonia', Aristotle is not referring to a state of psychological or emotional euphoria, nor to a set of abstract ideas about 'humanity', but to the activity of the soul in accordance with reason. In the twenty-first century Aristotle's premodern metaphysical notion of the 'soul' won't gain much traction, but a good equivalent concept would be 'the will or motivating causes of action' in accordance with reason. Aristotle maintained that human beings are uniquely capable of living according to the faculty of reason. He used the word virtue in the Greek sense, which is less about moral goodness and more about things fulfilling their unique purposes.

In Chapter 8 of the Nicomachean Ethics, Aristotle identifies 'the good of the soul' as higher than worldly goods and goods of the body. While all three goods are needed for complete happiness, Aristotle maintains that neither worldly goods nor goods of the body can alone bring happiness. Happiness is an activity of the soul and the happy person leads a good life. In Chapter 9, Aristotle acknowledges that while virtue is a necessary condition for happiness it is not a sufficient condition. Adversity and misfortune can prevent the virtuous person from attaining happiness. Nevertheless, without virtue a person cannot achieve the full well-being of which humans are capable. The key insight here is that eudaimonia involves the active engagement of the 
individual in fulfilling his own human purposes. Liberals and virtue ethicists alike reject the notion that an individual's complete eudaimonia could be provided by others. As such, the absence of harm and interference are more essential to an individual's well-being than goods bestowed by others could ever be. Happiness is an achievement, not a gift bestowed by those who proclaim to act in our 'best interests'.

Both J. S. Mill and his predecessor William Von Humboldt worried that the idea of virtue as a good in itself would be supplanted by the notion that virtue is instrumental to procuring a more immediate, hedonistic conception of happiness involving the pursuit of physical and material goods (Stonestreet 2009: 17). Happiness so conceived tends to be difficult to secure for all since humans tend to compete for the lion's share of such 'goods' and to measure the value of their possessions comparatively.

Mill's rejection of this simplistic notion of happiness separates his utilitarianism from Jeremy Bentham's more crude understanding of utility as 'the greatest good for the greatest number'. For Mill and Humboldt, actively participating in shaping one's own desires and impulses, as opposed to responding passively to a generic set of 'given' desires and impulses, is what it means to have character and to express one's uniquely human nature. When happiness is understood as a self-authored state of well-being, then the individual's pursuit of happiness is not commensurable to that of others, since there is no single standard of measurement. This tends to foster cooperation and to reduce competition for 'goods' conceived of in material terms alone. On this view, happiness is a state of being rather than a state of having. While having things may be a necessary condition, e.g. in securing certain tools or the time and freedom needed to accomplish goals, possessing these kinds of 'goods' is not sufficient to a person's happiness.

Happiness, conceived in the ethically serious sense as a life well lived, cannot be secured by governments or laws, whether secular or theocratic. However, it $\boldsymbol{i s}$ within the power of governments and social institutions to provide human beings with the external conditions indispensable to the pursuit of this kind of individual moral development. This will not guarantee the attainment of virtue or happiness, but it will ensure that all have the means necessary to its attainment and the liberty to pursue it. The key insight here is that no paternalistic institution or government can confer moral virtue upon a human being or make her a person of good moral character.

Mill argued that tolerance and liberty, along with minimal state interference, produce the best situation for individual human flourishing. He observed that governments and religious authorities are not infallible. Censoring lifestyles or viewpoints on the basis of their difference from our own would be to assume an infallibility that we do not possess. 
Mill further argued that social progress is aided by openness to a wide variety of views. Even mistaken views can contain partial truths, and so they should be permitted a hearing. The legitimacy of society's dominant beliefs rests upon their being tested from time to time against the merits of opposing arguments and perspectives. These challenges present an opportunity for the dominant beliefs to improve, not a threat. Challenges to the dominant beliefs also ensure that 'common sense' views will be held not in the manner of a prejudice, but in such a way that the reasons for holding them will be understood, since the arguments in their favor must be revisited from time to time and perhaps revised when appropriate. This will ensure that those who cherish these beliefs are truly persuaded of their merits, rather than clinging to them as foregone conclusions or 'dead dogmas'.

Liberalism, uniquely it seems to me, embodies (not only in word but in law) the belief that human beings are worthy of liberty, responsibility and selfdetermination. Liberalism's rejection of state paternalism rests partly on Mill's insight that the individuality that constitutes self-determination is essential to human flourishing. The wisdom of others is fallible and sometimes too narrow. Individuals know and care more about their own situation more than anyone else who might claim to be acting in 'their best interests'. If we open the door to ideologies that colonize the individual's negative liberty by the will of others acting in on their behalf or on 'God's', we will remove from the individual both the liberty and the responsibility essential to living a fulfilling life. Moreover, a moral life rests on the concept of individual agency, for only when we are able to make free choices can we be held accountable for our decisions, and for any benefit or harm they may produce for others. The concepts of praise and blame are grounded in autonomy and self-determination, such that the flip side of political freedom is political responsibility.

\section{In Defense of Social Liberalism}

In anticipation of my soi-disant liberal (and non-liberal) critics, I would like to say a few words in defense of social liberalism and liberal multiculturalism.

There can be no doubt that, where neoliberals have espoused unfettered capitalism, liberalism certainly has been competitive and not cooperative. It has at times stunted individuality and self-determination, not fostered them. It has deprived many of the conditions necessary for the pursuit of higher human values, i.e. those that reach beyond mere survival or basic security of life.

However, liberalism is fragmented from within, most notably in the economic sphere, where there is a gulf between classic liberalism and welfare liberalism. The former seems to have morphed into a neo-liberal hybrid creature that hates state intrusion into private wealth but loves inserting its tentacles into every other private crevice of individuals' lives. This, along with the development and monetization of new technologies, has resulted in an 
attenuation of the private sphere that Mill thought essential to the development of individuality and human flourishing.

Furthermore, it is no secret that, in modern democratic societies, the mass media is effectively in the hands of an oligarchy. This means that the voices of the corporate entities and elites who own the media set the cultural agenda and drown out alternative voices. Consequently, in today's liberal democracies, the free market and freedom of thought are often opposed. As Philosophy Now editor Grant Bartley has noted, the 'freedom' of capitalist liberal democracies is arguably the freedom to make profit—not the freedom of individuals (Bartley 2009: 21).

However, there are good liberal arguments for regulating markets, raising taxes for the super-rich, revising international trade agreements, and enforcing tough laws on multinational corporations. Applying the harm principle to corporations and nation states decades ago, before they grew onto enormous tails that wag the dog, could have prevented many of the economic inequities that now exist. While these reformist proposals may sound idealistic at this late stage of the game, the alternative is a cynical abandonment of politics, and resignation to the fact that we now live in a post-political world where only might makes right. The fact that some have failed (either by accident or by design) to adhere to the civic principles of political liberalism in practice (particularly in the economic sphere) is not a reason to abandon political liberalism's social and political principles altogether. It is a reason to work harder to make sure they are more effectively and consistently applied, enforced and preserved in the future, especially in the economic arena.

Western liberal universalism has its counterpart in political Islam (or PanIslamism), which presents a rival universalism to western liberalism in the form of an ahistorical and supranational 'Islam' devoid of internal diversity or contextualization. Professor Stephen Howe has argued that Islamism evidently functions in many parts of the world as a form of-or perhaps surrogate for-cultural nationalism. It is more of a transnational or supra-national ideology that cuts across borders and, in Howe's words, proclaims 'loyalties far more inclusive and compelling than any more localised identity-claim'. (Howe 2011: 28) In the context of Pan-Islamism, the word ummah is used to mean the Diaspora or Commonwealth of the Believers (ummat al-mu'minin), and thus the whole Muslim world. This generic Islam, with its mythical socio-cultural unity of the ummah is integral to Islamists' self-perception and not a fabrication of their most obtuse Western detractors.

Cultures are not homogeneous but complex. The idea that loose groupings of individuals with similar religion, backgrounds or language constitutes 'culture' rests on the assumption that all of the diverse individuals within that grouping belong to the same 'community'. The notion of a Muslim community presupposes a broad consensus on Muslim beliefs or practices. This is a 
political fiction. Where it appears real, the perceived unity is often achieved through violence, stigma, taboo or some combination of these.

Culture, where it is used to promote social cohesion by (over)emphasising a particular aspect of identity such as religious background, is often a form of oppression or captivity. Part of the definition of 'culture' is socialization. Where socialization is not based on free and informed choice, it is little more than indoctrination. As such, it amounts to an assault on individuality and self-determination and becomes a form of tyranny, stunting both individual and social development. This has been as true of cultures in the west as it is anywhere else.

Female (and male) feminists argue that multiculturalism is often little more than a concealed effort to enforce male power. The politics of cultural recognition become the legitimating narrative for continued female subordination. Thus multiculturalism highlights the victimization of the minority ethnic sub-culture by the dominant host culture, while obscuring the victimization of women by men within the ethnic subculture. Commenting on the adverse effects of state-sponsored multicultural accommodation, Political Science Professor Jan Feldman has argued that such a policy 'unwittingly entrenches male power within religions and cultures' and that this also applies in the international realm.

Internationally, organizations like the UN are squarely behind women's rights and gender equality. Nonetheless, the UN has made it a 'right' to have one's culture recognized, respected and preserved. Not surprisingly, as is the case at the national level, men speak for minority cultures and claim to represent their 'authentic' values. Moreover, the United Nations and the international human rights regime are relatively impotent in the face of respect for national sovereignty. Unless national governments put forward women-friendly domestic legislation and allocate funds for adjudication and enforcement of these provisions, international treaties and documents remain mere paper. (Feldman 2011: 197)

The cultural beliefs that multiculturalism seeks to preserve, maintain or extend are all too often deeply patriarchal. The drive to protect communities from one form of cultural domination effectively renders the other invisible. This only serves to uphold a double standard; it does nothing to eliminate cultural imperialism in principle, just as it does nothing to protect individual Muslims or other minorities within Muslim communities from harm.

Pluralist multiculturalism also fails individuals when it separates cultural identity from political/national identity and emphasizes the differences between them. As such, pluralist multiculturalism is essentially at odds with the political rule of nation states. Liberal democracies are nation states that provide the basis for democratic political rule. Pluralist multiculturalists divide their loyalties between culture and the broader political community made up 
by the host nation, often giving more allegiance to community and cultural values, which may be essentially incongruous with the laws that govern the nation state. This conflict of interest was exposed in a $2007 \mathrm{UK}$ report titled 'Living Apart Together' conducted by the UK think tank Policy Exchange. Their research found that among Muslims in Britain 28\% would prefer to live under sharia law. The report concluded, 'There is clearly a conflict within British Islam between a moderate majority that accepts the norms of Western democracy and a growing minority that does not.' (Mirza, Senthikumaran, and Ja'Far 2007: 5) Similarly, in Denmark The Integration Barometerwhich measures the degree of assimilation in the municipality among young people with a non-Western background-showed that almost one third of 1829 year olds $(31 \%)$ believe that 'religious and cultural laws must be adhered to, even though they may be contrary to [Danish] law' (Bergman 2019).

These observations about conflicts between national and community laws are particularly relevant to Muslim women who, despite living in secular countries, often face marital captivity and forced or child marriage. In August 2018, the UK's Centre for Secular Space appealed to the British government to stop pushing minority women towards religious courts, which (as mentioned above) it has done by means of its application for a divorce (Form D8). This formal legal document actively encourages women to turn to religious bodies and implies, misleadingly, that that a religious dissolution of marriage is a requirement, while also suggesting that women should seek guidance not from civic advisors but from religious authorities. In response to these realities, The Centre for Secular Space stated:

Our research shows that the power and control of religious fundamentalist networks over Muslims has grown enormously over the last thirty years. This has led to a widespread belief that a civil marriage is not necessary, that women must have a divorce certificate issued by a Sharia 'court' in an apparent judicial procedure; and that they must get this 'certificate' even if they already have a civil divorce (CSS, August 2018).

Finally, the politics of cultural recognition and assertion undermine the idea of a common humanity, limiting people's sense of moral responsibility to members of their own community. This leads to moral relativism and the rejection of universal human rights. This refusal to recognize universal Human Rights such as those enshrined in the United Nations Declaration of Human Rights has been led by states aligned with the Organization of Islamic Cooperation (OIC). In the 1980's and 90's, the OIC drafted an alternative declaration, which they refer to as 'The Cairo Declaration of Human Rights in Islam'. 
Following a conference on humanitarian law and Islamic law that took place in Islamabad in 2005, journalist Hadia Nusrat summarized the findings of the legal experts with this caveat:

Despite its many overlaps with the Islamic law, Muslim scholars maintained that [International Humanitarian Law] is a man-made law and only acceptable to Muslims so long as it does not conflict with the Shari'a. Islamic law has greater primacy for Muslims as it is a matter of their faith that allows no room for deviation (Nusrat 2012).

Despite the OIC's rejection of Universal Human Rights, feminist Gita Sehgal and others have pointed to the important roles played by many non-Western contributors to the United Nations Declaration of Human Rights. These include Hansa Mehta of India and Charles Malik of Lebanon, whose significant additions helped to shape key parts of the UNDHR, as well as a number of Muslim delegates who supported the clause protecting the free exercise of religion. The Foreign Minister of Pakistan, Zafrallah Khan, even quoted the Qur'an: 'Let him who chooses to believe, believe and him who chooses to disbelieve, disbelieve.' Cyrus the Great, founder of the Persian Achaemenid dynasty (550$329 \mathrm{BC}$ ) is said to have issued the first recorded written declaration of human rights. It would be simplistic to assume that universal human rights are an entirely western construct.

To identify the emphasis on individual liberty and self-determination as essentially ‘western' concerns as though they were alien to non-European cultures is to deny the main thrust of anti-Colonial politics. Even robust criticisms of liberal values and lifestyles trade in liberalism's currency of free expression-a currency that some critics of the UNDHR deny to their own detractors at home. Islamic spokespersons' responses to apostasy, for example, vary. In many cases rejection of Islam by Muslims is seen as a punishable offense that would incur execution or, in other cases, fatwa. There have been some prominent cases that highlight the extreme responses to criticism or satire of Islam. Mohamed Geele's attack on Danish editorial cartoonist Kurt Westergaard following the publication of his cartoons in the Danish newspaper Jyllands-Posten is one example. Another is the 2004 murder of Theo Van Gogh, the Dutch journalist who collaborated with the Dutch-Somali feminist Ayaan Hirsi Ali to make a film about women and Islam. The murderous response to Charlie Hebdo's satirical take on religion is a more recent case study in Islamist intolerance.

The laws in liberal democracies reflect widely accepted norms about the freedoms necessary for human beings to flourish (many of which are also inscribed in documents such as The European Convention on Human Rights and The Universal Declaration of Human Rights). Freedoms claimed in the latter document include, but are not limited to, 'freedom of speech and belief 
and freedom from fear and want' and 'freedom to change [one's] religion or belief'. Given the wide-ranging international support for such documents, it would be misleading to describe them as symptomatic of a 'western' view or of 'cultural imperialism'. The following countries voted in favor of the Declaration: Afghanistan, Argentina, Australia, Belgium, Bolivia, Brazil, Burma, Canada, Chile, China, Colombia, Costa Rica, Cuba, Denmark, the Dominican Republic, Ecuador, Egypt, El Salvador, Ethiopia, France, Greece, Guatemala, Haiti, Iceland, India, Iran, Iraq, Lebanon, Liberia, Luxembourg, Mexico, Netherlands, New Zealand, Nicaragua, Norway, Pakistan, Panama, Paraguay, Peru, Philippines, Thailand, Sweden, Syria, Turkey, United Kingdom, United States, Uruguay, and Venezuela.

\section{The Paradox of Tolerance}

We arrive at the important question of whether a liberal society should tolerate a minority culture that doesn't respect its values.

Suppose an intolerant minority community rejects dissent within its own ranks. Leaders of this community refuse to acknowledge that other points of view-whether internal or external—could be true. If such a community were to grow and become the majority, it would establish legal and social sanctions against those who dissent from its doctrines or teachings. Therefore, ultimately we would not increase autonomy, liberty or tolerance by being tolerant towards such a community. As the intolerant community grows, our immediate tolerance in the short-term would have contributed (in the long run) to an overall decrease in tolerance in the society at large.

But we might still be guilty of a contradiction in refusing to grant tolerance to this minority culture. It would seem contradictory for a tolerant liberal person to advocate for 'experiments in living' and then to say, 'unless you choose a way of living that liberals disagree with.' It could be argued that being part of a conservative or even authoritarian culture can be an expression of autonomy, of living as one thinks best.

Liberalism is expressly anti-ideological because it requires state neutrality with respect to ideological visions of 'the good life'. Its demands on citizens are very minimal. The aim of the liberal state is not to make people good (according to a 'Western ideology') but to create the conditions within which the free pursuit of moral virtue ('the good life', as each defines it) is conceptually coherent. Through its application of the harm principle, liberal states secure the individual's negative liberty (freedom from coercion by others) so that she may pursue goals that are genuinely her own, so long as she does not harm others in the process. Liberal states defend the right of individuals to live as they think best, within the minimal limits of the harm principle. Mill's Harm Principle states: 'The only purpose for which power can be rightfully exercised over any member of a civilized community, against his will, is 
to prevent harm to others.' Political liberalism has been more successful than any previous political system in promoting an expansion of rights to minorities because of its underlying insight that, without liberty and self-determination, moral agency (and therefore moral virtue) becomes incoherent and human happiness dwindles.

The beliefs and values (but not all of the practices) of an intolerant/conservative minority sub-culture can be-and are-tolerated in liberal nation states without contradiction. Since the host society is liberal, individuals have certain rights that protect their negative liberty (freedom from interference) to pursue their own good in their own way. However, if the intolerant subculture's practices violate the Harm Principle, for example, by using violence against other members of the community who dissent, then a liberal society cannot tolerate those practices any more than they would tolerate other illegal activities. The reason liberal states outlaw certain forms of coercion is to protect negative liberty (freedom from coercion) for all members of society equally.

Every attempt to draw a line between what is acceptable and what is not acceptable in a civil society is not 'intolerance'. The idea that giving people legal protections from harm makes one 'intolerant' rests on a confused definition of tolerance. If any state gave people complete freedom to harm others in any way a community deemed 'right', this would not be a government, but a state of lawless anarchy. It would also give carte blanche to majority groups-or any group capable of dominance, intimidation or manipulative power-to abuse and coerce others to obey its will. No one (except anarchists) argue that the state should never interfere with peoples' absolute freedom. Rather, the question is which kinds of interference into citizens' liberty are fair and which will promote a tolerant society.

In a liberal state, a religious fundamentalist who denies others the right to self-determination is not prevented from living his own life according to the doctrines of his chosen religion. He is merely prevented from coercing others to do so. In the liberal view, 'intolerance' refers to practices that deny the value of tolerance itself. When liberals label community leaders or individuals who refuse to permit to others the expression of diverse views or life choices as 'intolerant', we are not being prejudiced or bigoted. We are not rejecting the value of tolerance when we level our criticisms at intolerant religious leaders. Nor are we denying anyone the right to pursue their own good in their own way. When we describe theocrats (for example) as intolerant, we are consistently defending the value of tolerance. We can maintain that beliefs and values contrary to tolerance may be expressed while also maintaining that certain practices cannot be, since only the latter would violate the harm principle and prevent those who disagree from exercising the 
same rights. It is precisely this lack of reciprocity in rights and entitlements that uniquely characterizes the religiously intolerant group or individual.

A refusal to permit harmful forms of coercion is quite different from an intolerant ideological system. Intolerant ideologies impose a specific way of living on people. Liberals accept that many people choose to live their own lives according to strict religious rules that are illiberal. Tolerant liberals recognize the rights of individuals to hold views that are theocratic, homophobic, sexist and contrary to reason. In Chapter 4 of On Liberty, 'Of the limits to the authority of society over the individual', J.S. Mill expressly argued that a person's feelings for his own opinion are not comparable to the feelings of others who are offended by his holding it. To treat both as though they are equivalent is like saying that the desire of the thief to take a purse and the desire of the rightful owner to keep it deserve equal respect (Collini 1989: 84). Mill's conception of liberalism is carefully designed to protect the individual's freedom to hold and to express his own views with impunity, while at the same time protecting the equal liberty of others to do the same.

Some will argue that making value judgments (such as the judgment that tolerance is valuable) is just one way of looking at the world. As such, westerners or liberals have no right to impose it on others who disagree. Liberals follow Mill in rejecting this kind of thoroughgoing moral relativism. Whether they admit it or not, theocrats and authoritarians do too. Mill's liberal political philosophy provided a means of allowing diverse points of view to be expressed in a manner that does not require everyone to give equal credence to every point of view. Morals are not about a person's or a culture's feelings or opinions. There are evidence-based facts about whether or not an action or a policy contributes to human flourishing, and about whether or not a policy provides equal rights and protections to all parites concerned. For example, depriving people of fundamental liberties and human rights is either bad for them or it benefits them and their wellbeing. Mill (following Humboldt) was not concerned only with what is immediately gratifying, but with whether an action or policy contributes to human wellbeing in the long term. He recognized that many things that are immediately unpleasant are nevertheless beneficial to us. Examples abound, whether eating your vegetables, taking vigorous exercise or studying for an examination.

It might be tempting to ban civil liberties during a moment of perceived 'crisis' or in response to the (currently) powerful government's short-term interests, but Mill thought this was illegitimate. It may be true that public debate often involves arguments that are persuasive only because of emotive appeal, or spurious claims. One view is that if we allow pernicious falsehoods a public airing, we're providing the soil in which they can grow into dangerous actions. If we censor the distorted claims of far right organizations like the $B N P$ or Marine Le Pen's Front Nationale, no one can hear their arguments, 
and hence no one can be encouraged to form the false beliefs associated with them.

Liberals respond to arguments for censorship by pointing out that, in the long run, and in a climate of lively debate, worse opinions give way to better ones, and false opinions give way to true ones. The only reason we have for our confidence that our politically correct views are correct is that we've allowed them to be challenged and remain undefeated, even though there has been ample opportunity for debating them. Unless we allow heretical opinions to be tested in this manner, our confidence that they are wrong is based on dogmatism, not reason. Where such views are censored there is a 'chilling effect' on expression and thought, and we cast a pall of orthodoxy over the political culture. This undermines intellectual courage and, ultimately, social progress. Those who imagine themselves best fit to lead ought to be most confident in their ability to use reason and argument to defeat baseless viewpoints. Unless 'heretical' opinions are demonstrated to be false in open public forums, they will not die, but fester under the surface where resentments are harbored and crystallized, threatening social stability in the long run. I can think of no past historical situation where bad ideas took root and became catalysts to actual harm except in situations where the freedom to argue against them was curtailed or suppressed, and/or where people were too fearful or too indolent to air their objections. In a climate of open debate bad ideas are rooted out and supplanted by better arguments. Sometimes the common sense view, once tested, even gives way to a new contender, or a heretical viewpoint. Much social progress has happened in this manner.

Making value judgments is not, in itself, intolerant. Tolerant people $d o$ make value judgments and do not become intolerant when they express their views or values. The idea that tolerance requires silent passivity in the face of 'the Other's' beliefs fails to understand what tolerance is. One is not tolerating an attitude or behavior if she has no strong opinion on the matter or if she has no choice but to put up with it because she is intimidated to accept it. Tolerance is not indifference or weakness. Rather, toleration is a principled form of voluntary inaction intended to protect the free flow of ideas in society and the continued possibility of debating values. This is important so that we may be genuinely informed of our alternatives and permitted to hold the beliefs that we really find most persuasive. Tolerance only applies in circumstances where one deliberately chooses to forebear behaviors or beliefs of which one disapproves. A tolerant person forbears ideas she disagrees with because of overriding values that are in the public interest. These values are more important than the offence given by the (tolerated) belief or practice.

Tolerance requires neither silent nor passive acceptance of objectionable beliefs and ideas. Short of using force to impose their views on others, tolerant individuals accept and encourage all methods of influencing people- 
from speech and satire to public demonstrations and debates. Tolerance requires an objection component, otherwise it is just indifference. Tolerance requires opposition or disagreement, but it does not involve acting on this disagreement in a manner that suppresses the view that one disagrees with. A genuinely liberal society welcomes and encourages lively debate, discussion, and civil disagreement-not stolid political correctness or the censorship of ideas perceived as illiberal or intolerant.

Renowned philosopher of science Sir Karl Popper (1902-1994) was fully aware of the danger in censoring intolerant attitudes. He thought it preferable to counter them with rational argument and keep them in check by public opinion. However, he thought that society has a right to suppress intolerant attitudes if their spokespersons refuse to engage in rational argument and refuse their followers the right to hear alternative views:

Unlimited tolerance must lead to the disappearance of tolerance. If we extend unlimited tolerance even to those who are intolerant, if we are not prepared to defend a tolerant society against the onslaught of the intolerant, then the tolerant will be destroyed, and tolerance with them (Popper 1962 [1945]: 543).

No one should be made, by legal or political force to conform to the values of an ideology that is not his or her own, including a liberal ideology. The only exception to this is in situations where the reason for state interference is to prevent harm to others. This ensures that the same liberty be granted to all citizens reciprocally rather than unilaterally (as it is under pluralist multiculturalism and theocracy).

What, then, constitutes harm? Being offended does me no serious harm. Having my beliefs tested by contrary ideas allows me to reflect upon my own beliefs and to think critically about how well they fare in the face of competing ideas. Following J. S. Mill, liberals believe that real harm is that which is injurious to my 'permanent interests as a progressive being'. Arguably, exposure to a multitude of ideas it is not what harms these interests, but rather lack of it. Never being exposed to anything that offends me can stunt my growth and hinder my intellectual and/or moral development and thus harm my permanent wellbeing in a way that having my parochial beliefs offended does not.

Willing recruits to an intolerant ideological belief system are another matter. There is nothing wrong with an ideological community requiring that its willing adherents honor its beliefs. If some in good conscience cannot accept those beliefs or attitudes then there is no reason why the community should not be permitted to exclude them.

But intolerant ideologies, by definition, are not interested in communities of willing believers, or else they would be tolerant. The concept of 'intolerance' means more than verbal objection to others' views; that is what tolerance 
implies. Rather 'intolerance' means rejection of the other's fundamental right to self-determination and unwillingness to withstand their dissent. Intolerant individuals or groups dictate how others must live.

Westerners have been intimidated by spurious accusations of 'racism', 'Islamophobia' (a neologism used to censor dissent) and 'ethnocentrism' into surrendering their freedom to offend. Often their accusers are themselves middle class academics with prestigious posts at European or American Universities who are not subject to the constraints of theocratic laws but presume to speak on behalf of those who are. To the extent that western Europeans and Americans have been reluctant to criticize repressive forms of coercion by intolerant belief systems, they have colluded with these self-appointed 'representatives' and ideologues.

When Western 'identity liberals', refuse to legislate against or even to verbally object to censorship or to Sharia courts within their own national borders because of misguided ideas of political correctness, they are not expressing liberal values. As King's College London's Executive Director of Culture Munira Mirza wrote in response to the British newspapers' refusal to re-print the cartoons of Mohammed that first appeared in the Danish newspaper Jytllands Posten, '.. sympathetic lefty anti-racists who believe censorship will protect Muslims are actually missing the point. Many Muslims want the same freedoms as everyone else to debate, criticize and challenge their religion' (Mirza 2006).

Social progress is only possible where there is openness to a wide variety of views. This applies as much within a culture or community as it does between diverse communities. No individual or group of human beings is infallible. None of us has the requisite authority to dictate to others what constitutes 'the common good'. Liberalism establishes the conditions within which we can each pursue and express our fallible ideas of what does.

\section{Bibliography}

Bartlett R, Collins SS (2011) Aristotle's Nicomachean Ethics: A New Translation. Chicago, IL: University of Chicago Press.

Bartley G (2009) Knowledge \& History. Philosophy Now 76(*): 21.

Bergman J (2019) Denmark: How to Deal with Integration? Gatestone International Institute International Policy Council.

Blackburn S (2007) Religion and Respect. In Louise M. Anthony (ed.) Philosophy Without Gods: Meditations on Atheism and the Secular Life. Oxford: Oxford University Press.

Collini S, ed (1989) On Liberty and Other Writings. Cambridge: Cambridge University Press. 
Brown W, Forst R (2014) The Power of Tolerance: a Debate. New York, NY: Columbia University Press.

Centre for Secular Space (2017) Why Regulation is Not the Answer: 15 Black and Minority Women's Rights Campaigners Explain. London, United Kingdom.

Centre for Secular Space (2018) We Call on the British Government to Stop Pushing Minority Women Towards Religious Courts. London, United Kingdom.

Camden: Your Guide to Social Services (October 2018) Help Us to Fight Hate Crime London: Camden Council.

Cliteur P, Herrenberg T, eds (2016) The Fall and Rise of Blasphemy Law. Leiden: Leiden University Press.

Einhorn B (1991) Shifting Territories: Feminism and Europe. Feminist Review $39(*): 16-36$.

Feldman J (2011) Citizenship, Faith and Feminism: Jewish and Muslim Women Reclaim their Rights. Waltham, MA: Brandeis University Press.

Heywood A (2009) Multiculturalism, Identity and Diversity. Politics Review 19(1): 25-28.

Howe S (2011) Aftershock. The New Humanist 126(5): 28.

Leiter B (2013) Why Tolerate Religion? Updated Edition, Princeton, NJ, and Oxford: Princeton University Press.

Mirza M (2006) Comment: Munira Mirza on the Danish Cartoons, Freedom of Expression. Wannabehuman.blogspot.com, February 6.

Mirza M, Senthikumaran A, Ja'far Z (2007) Living Apart Together: British Muslims and the paradox of multiculturalism. London: Policy Exchange.

Nusrat H (2005) Humanitarian Law and Islam. The Magazine of the International Red Cross and Red Crescent Movement 1(*): 24-25.

Popper KR (1962) [1945] The Open Society and Its Enemies, Complete Volumes I \& II. London and New York, NY: Routledge.

Stonestreet E (2009) On Individuality. Philosophy Now 76(*): 17-18. 